\title{
The Effectiveness of Different Diet Strategies to Reduce Type 2 Diabetes Risk in Youth
}

\author{
Megan L. Gow 1,2, , Sarah P. Garnett ${ }^{1,2}$, Louise A. Baur ${ }^{1,2}$ and Natalie B. Lister 1,2 \\ 1 The Children's Hospital at Westmead, Westmead 2145, Australia; sarah.garnett@health.nsw.gov.au (S.P.G.); \\ Louise.Baur@health.nsw.gov.au (L.A.B.); natalie.lister@health.nsw.gov.au (N.B.L.) \\ 2 The Discipline of Child and Adolescent Health, The University of Sydney, Westmead 2145, Australia \\ * Correspondence: megan.gow@health.nsw.gov.au; Tel.: +61-2-9845-3119; Fax: +61-2-9845-3170
}

Received: 15 June 2016; Accepted: 4 August 2016; Published: 9 August 2016

\begin{abstract}
Type 2 diabetes in children and adolescents has become a prominent clinical issue in recent decades. Increasing numbers of young people have risk factors for type 2 diabetes, particularly obesity, indicating the need for effective type 2 diabetes prevention strategies. The aim of this review was to identify specific dietary strategies that optimize improvements in risk factors for type 2 diabetes in youth and hence reduce the risk of type 2 diabetes development. Our review of the current literature indicates that dietary interventions lead to weight loss when intervention adherence is high. However, in addition to weight loss, a diet that is reduced in carbohydrates may optimize improvements in other type 2 diabetes risk factors, including insulin resistance and hyperglycemia. While further research is needed to confirm this finding, reduced carbohydrate diets may include a very low-carbohydrate diet, a very low-energy diet, a lower-glycemic-index diet, and /or an intermittent fasting diet. This array of dietary strategies provides a suite of intervention options for clinicians to recommend to young people at risk of type 2 diabetes. However, these findings are in contrast to current guidelines for the prevention of type 2 diabetes in adults which recommends a low-fat, high-carbohydrate diet.
\end{abstract}

Keywords: type 2 diabetes; obesity; prevention; child; adolescent; youth; carbohydrate; diet intervention

\section{Introduction}

Increases in obesity rates around the world over the last several decades have preceded the emergence of type 2 diabetes (T2DM) in children, adolescents, and young adults as an important clinical issue; now affecting up to $5.3 \%$ of $0-19$ years old in certain populations [1,2]. In the past decade, research has demonstrated the aggressive nature of T2DM in young people, including the early development of diabetes-related complications which ultimately lead to premature mortality [3-7]. These factors highlight the importance of developing effective prevention strategies.

To the best of our knowledge, there have been no interventions conducted in young people with the primary end point being a reduction in T2DM incidence. This type of study would be difficult to undertake due to the number of children and adolescents who develop T2DM and the potentially long follow-up that would be required to detect an incidence reduction.

However, several risk factors for T2DM are modifiable, including obesity, features of the metabolic syndrome (including abdominal obesity, elevated triglycerides, low high density lipoprotein cholesterol (HDL-C), high blood pressure, and elevated plasma glucose [8]), insulin resistance, sedentary behaviour, and the intrauterine environment. Targeting these factors should facilitate a reduction in the risk of T2DM. A number of intervention studies conducted in children and adolescents aim to reduce obesity and concomitantly measure changes in other important modifiable risk factors, including 
insulin resistance and features of the metabolic syndrome. Such trials can indicate important strategies for reducing the risk of T2DM in young people.

In this review we aim to identify specific dietary patterns and/or macronutrient distributions that optimise improvements in prominent modifiable risk factors for T2DM, i.e., obesity, insulin resistance, and features of the metabolic syndrome in youth at increased T2DM risk, i.e., youth with at least one modifiable T2DM risk factor. Identification of optimal strategies may guide clinicians in their dietary prescription for youth at increased risk of T2DM.

\section{Systematic Reviews of Dietary Interventions for Obesity Treatment}

When aiming to reduce the risk of a young person developing T2DM, a dietary intervention will often aim to contribute to an energy deficit to improve weight status, which is the leading contributor to T2DM. Systematic reviews of randomised controlled trials (RCTs) of obesity treatment in children and adolescents acknowledge that lifestyle interventions incorporating a dietary component are effective (i.e., result in weight loss) up to 12 months from baseline [9-11]. The 2013 systematic review by Ho and colleagues demonstrated a reduction in body mass index (BMI) of $-1.25 \mathrm{~kg} / \mathrm{m}^{2}$, with $95 \%$ confidence interval (CI) -2.18 to -0.32 from lifestyle interventions compared with no treatment controls and also reported that, compared with usual care, lifestyle interventions led to significant improvements in fasting insulin, insulin resistance, blood lipids, and blood pressure [9]. The Stop/Traffic Light and caloric restriction approaches were the most commonly reported dietary interventions in that systematic review.

While systematic reviews highlighted the importance of dietary intervention for the treatment of obesity, they did not investigate the potential advantage of any particular dietary pattern and/or macronutrient distribution for weight loss and improving other T2DM risk factors.

\section{Macronutrient Distribution of the Diet and Weight Loss}

There has been much interest in recent years on whether there is an optimal dietary macronutrient distribution for weight loss, particularly in adults. Our 2014 systematic review with meta-analysis examined, for the first time, whether variations in dietary macronutrient content differentially affect changes in weight and cardio-metabolic risk factors in children and adolescents who are overweight or obese [12]. Overall, the review indicated improved weight status in children and adolescents undergoing obesity treatment, irrespective of the macronutrient distribution of a reduced-energy diet.

\section{Macronutrient Distribution of the Diet and Improvements in T2DM Risk Factors}

While there may not be an impact on weight loss, findings from our 2014 systematic review did suggest the potential for the specific application of certain macronutrient distributions to target certain T2DM risk factors [12].

\subsection{Very Low-Carbohydrate vs. "Traditional" Low-Fat, High-Carbohydrate Diet}

Conventionally, a "low-fat" diet approach (typically aiming for approximately $45 \%-65 \%$ of daily energy as carbohydrate, $<35 \%$ as fat and $\sim 15 \%$ as protein, Table 1) has been utilised in child and adolescent obesity treatment programs, including the Stop/Traffic Light diet [13-15] and a standard caloric restriction approach [16-18]. Large T2DM prevention studies in adults demonstrate that a low-fat, high-carbohydrate diet is effective in the prevention of T2DM, reporting reductions in T2DM incidence of 58\% after approximately 3 years of intervention and follow-up [19-23]. Conversely, this low-fat, high-carbohydrate diet approach has been postulated to promote hyperglycaemia and compensatory hyperinsulinemia which may lead to more rapid progression of T2DM in susceptible individuals [24]. It has been suggested that alternative dietary patterns and macronutrient distributions may facilitate prevention of T2DM by reducing postprandial glucose and insulin levels, improving glucose and lipid metabolism, and preserving $\beta$ cell function [24,25]. 
Table 1. Classification of diets based on carbohydrate content (modified from Liebman, 2014 [26]).

\begin{tabular}{lll}
\hline \multicolumn{1}{c}{ Carbohydrate Diet Classification } & Amount of Carbohydrate & \multicolumn{1}{c}{ Example of Dietary Pattern } \\
\hline Typical/high-carbohydrate diets & $45 \%-65 \%$ of total calories & $\begin{array}{l}\text { Low-fat diet, STOP/Traffic light diet, } \\
\text { Standard-protein diet, lower-GI diet }\end{array}$ \\
\hline $\begin{array}{l}\text { Moderately restricted } \\
\text { carbohydrate diets }\end{array}$ & $26 \%-44 \%$ of total calories & $\begin{array}{l}\text { Intermittent fasting diet, } \\
\text { increased-protein diet }\end{array}$ \\
\hline Low-carbohydrate diets & $\begin{array}{l}51-130 \mathrm{~g} / \text { day (or approximately } \\
16 \%-26 \% \text { of calories of a 2000 } \\
\text { calorie diet) }\end{array}$ & Low-carbohydrate diet, Paleo style diet \\
\hline Very low-carbohydrate diets [27-29] & $\begin{array}{l}\text { Typically } 20-50 \mathrm{~g} / \text { day or } 5 \%-15 \% \\
\text { of total calories }\end{array}$ & $\begin{array}{l}\text { Very low-carbohydrate diet, very } \\
\text { low-energy diet, Atkins diet }\end{array}$ \\
\hline
\end{tabular}

A popular alternative to the low-fat diet is a very low-carbohydrate diet (typically aiming for $<50 \mathrm{~g}$ carbohydrate per day, Table 1) with high or ad libitum fat and/or protein intakes (e.g., the Atkins diet). In the 2014 systematic review examining the effect of varying the macronutrient distribution of a reduced energy diet in the treatment of child and adolescent obesity [12], three of the included studies reported improved insulin levels and/or insulin resistance in the very low-carbohydrate group compared with the low-fat group immediately following active treatment $[27,28]$ or at follow-up [29], described in Table 2. Studies demonstrating an advantage of the very low-carbohydrate diet generally had a better methodological quality score and larger sample size and were more recently conducted studies compared with studies which found no differences between diet groups. Although results were not consistent, findings suggest that there may be a particular benefit of a very low-carbohydrate diet in facilitating improvements in hyperinsulinemia as part of obesity treatment compared with a traditional low-fat approach in children and adolescents with obesity, at least in the short-term.

\subsection{Increased-Protein vs. "Traditional" Standard-Protein, (Low-Fat) Diet}

Another popular alternative to a conventional low-fat approach is a moderate-carbohydrate, increased-protein diet (typically aiming for approximately $26 \%-44 \%$ of daily energy as carbohydrates, $<35 \%$ as fat and $20 \%-40 \%$ as protein). Increased-protein diets are posited to lead to greater weight loss by evoking sustained satiety despite negative energy balance, and sustaining energy expenditure despite loss in body mass by sparing loss of fat free mass [30].

In our 2014 systematic review examining the effect of varying the macronutrient distribution of a reduced-energy diet for the treatment of child and adolescent obesity, six studies compared an increased-protein and a "traditional" standard-protein diet. Most studies found improvements following the intervention for weight, fasting glucose, fasting insulin, insulin sensitivity, blood lipids, and blood pressure, but no study found any advantage of either diet [12]. Since this review, two further studies have been published reporting similar findings [31,32].

In adults, a 2012 systematic review of 24 trials demonstrated that an increased-protein diet compared to an isocaloric standard-protein diet can produce greater reduction in weight $(-0.79 \mathrm{~kg}$; $95 \%$ CI: $-1.50,-0.08 \mathrm{~kg})$, fat mass $(-0.87 \mathrm{~kg} ; 95 \% \mathrm{CI}:-1.26,-0.48 \mathrm{~kg})$, and triglycerides $(-0.23 \mathrm{mmol} / \mathrm{L} ; 95 \% \mathrm{CI}:-0.33,-0.12 \mathrm{mmol} / \mathrm{L})$, with better preservation of fat free mass and resting energy expenditure [33]. However, changes in fasting plasma glucose, fasting insulin, blood pressure, total cholesterol, low density lipoprotein cholesterol (LDL-C), and HDL-C were similar across dietary treatments [33].Together, these findings suggest that increasing the protein content of a reduced-energy diet, without a concurrent severe restriction on carbohydrate intake, does not affect the ability of a reduced energy diet to prevent the development of T2DM, compared with a standard low-fat diet approach. 
Table 2. Findings from studies examining the effect of various dietary patterns on type 2 diabetes risk factors in youth.

\begin{tabular}{|c|c|c|c|}
\hline Dietary Patterns & Studies & Weight Outcomes & Other Outcomes \\
\hline $\begin{array}{l}\text { Very low-carbohydrate } \\
\text { vs. low-fat diet }\end{array}$ & Gow et al., 2014 [12] ${ }^{1}$ & $\begin{array}{l}\text { Possible short-term } \\
\text { benefit of very } \\
\text { low-carbohydrate diet }\end{array}$ & $\begin{array}{l}3 \text { studies from review [27-29] } \\
\text { report greater benefit of very } \\
\text { low-carbohydrate diet for } \\
\text { improving insulin resistance }\end{array}$ \\
\hline $\begin{array}{l}\text { Increased-protein vs. } \\
\text { standard-protein diet }\end{array}$ & $\begin{array}{l}\text { Gow et al., } 2014[12]^{1} ; \\
\text { Garnett et al., } 2014 \text { [31] }^{2} \\
\text { Truby et al., } 2016[32]^{2}\end{array}$ & $\begin{array}{l}\text { No differences observed } \\
\text { between groups }\end{array}$ & $\begin{array}{l}\text { No differences observed } \\
\text { between groups }\end{array}$ \\
\hline $\begin{array}{l}\text { Lower vs. higher } \\
\text { glycemic index diet }\end{array}$ & $\begin{array}{l}\text { Parillo et al., } 2012 \text { [34] }^{2} ; \\
\text { Iannuzzi et al., } 2009[35]^{2} ; \\
\text { Joslowski et al., } 2015[36]^{2} ; \\
\text { Damsgaard et al., } 2013 \text { [37] }\end{array}$ & $\begin{array}{l}2 \text { studies }[34,36] \text { report } \\
\text { significant benefit of } \\
\text { lower glycemic index }\end{array}$ & $\begin{array}{l}3 \text { studies }[34,35,37] \text { report } \\
\text { greater benefit of lower } \\
\text { glycemic index for improving } \\
\text { insulin resistance }\end{array}$ \\
\hline $\begin{array}{l}\text { Very low-energy diet vs. } \\
\text { low-fat diet }\end{array}$ & $\begin{array}{l}\text { Figueroa-Colon et al., } 1993[38]^{2} \text {; } \\
\text { Berkowitz et al., } 2011[39]^{2}\end{array}$ & $\begin{array}{l}\text { Greater short-term } \\
\text { weight loss and } \\
\text { preservation of lean } \\
\text { body mass in very } \\
\text { low-energy diet }[38,39]\end{array}$ & $\begin{array}{l}\text { No differences between } \\
\text { intervention groups reported } \\
\text { to date }\end{array}$ \\
\hline $\begin{array}{l}\text { Intermittent modified } \\
\text { fasting }\end{array}$ & $\mathrm{N} / \mathrm{A}$ & $\mathrm{N} / \mathrm{A}$ & $\mathrm{N} / \mathrm{A}$ \\
\hline
\end{tabular}

\section{Glycemic Index of the Diet}

The glycemic index (GI) of carbohydrates is also an important dietary factor to consider. A diet that is lower in GI generally refers to a balanced diet that incorporates carbohydrate foods which are of a reduced glycemic load, i.e., foods/meals that produce a slower rise in blood glucose levels and have lower overall carbohydrate content [40]. Intervention studies in adults and children demonstrate that diets aiming for a lower-GI are safe and effective for improving insulin secretion, insulin resistance, body weight, and body composition [41-45]. A six month RCT in children with obesity comparing a lower-GI (GI: 60) versus higher-GI (GI: 90) hypocaloric diet found that waist circumference, BMI $z$ score, and insulin resistance were significantly reduced in the lower-GI compared with the higher-GI diet group [34]. In another RCT, 26 children were randomly assigned to either a hypocaloric lower-GI (GI: 60) or a hypocaloric higher-GI (GI: 90) diet. After six months, insulin resistance was significantly reduced only in the lower-GI diet group (homeostatic model assessment of insulin resistance (HOMA-IR); higher-GI, baseline: $3.2 \pm 1.6,6$ months: $3.2 \pm 1.8, p=0.98$; lower-GI, baseline: $3.1 \pm 1.5,6$ months: $2.4 \pm 1.1, p=0.04$ ) [35]. In another RCT, consumption of a higher glycaemic load diet was associated with less weight loss even when adjusted for sex and pubertal status $\left(R^{2}=0.11, p=0.007\right)$ [36]. However, the association was no longer significant when adjusted for total energy intake of the diet [36].

The Diet, Obesity and Genes (DiOGenes) study is the largest study conducted to date to examine the effect of varying the GI and protein content of a diet on weight and cardio-metabolic outcomes in children, recruiting families from eight European countries. Eligible parents were randomised as a family unit to one of five ad libitum diets: low-protein and low-GI; low-protein and high-GI; high-protein and low-GI; high-protein and high-GI; and control diet (national dietary guidelines; medium protein content and no instructions on GI) [46]. A difference of 15 GI units between the high-GI and low-GI diets was targeted [46]. The results of this study showed that neither GI nor protein had an isolated effect on body composition among children following an ad libitum diet. However, the low-protein, high-GI combination increased body fat, whereas the high-protein, low-GI combination was protective against obesity [47].

Cardio-metabolic risk factors, including fasting glucose, fasting insulin, and HOMA-IR, were assessed in 253 of the 817 children in the DiOGenes study. In this sub-sample, the children following a high-protein diet had significant reductions in waist circumference and serum LDL cholesterol 
compared with the low-protein diets [37]. No effect of GI was observed in this sub-sample. However, in the children who were deemed to have had high adherence to their intervention, waist circumference $(p=0.004)$, diastolic blood pressure $(p=0.007)$, mean arterial pressure $(p=0.005)$, fasting insulin $(p=0.013)$, and HOMA-IR $(p=0.016)$ were reduced in the high-protein compared with the low-protein diets, and serum insulin and insulin resistance were reduced in the lower-GI compared with the higher-GI diets $(p=0.04)$ [37]. Of note, the children in the DiOGenes study were children of parents who were overweight or obese and also included healthy weight children who were not necessarily at increased risk of developing T2DM. The children were not given advice on weight loss but were educated on the diet's ability to regulate appetite [47].

\section{Very Low-Energy Diet}

A very low-energy diet (VLED) is a non-conventional dietary approach that has gained popularity due to its association with rapid weight loss. It is a very strict diet aiming for $<800 \mathrm{kcal} /$ day. VLEDs are largely protein based, and contain essential fatty acids, vitamins, and minerals, but very little carbohydrates (typically $<50 \mathrm{~g}$ ), and are aimed at inducing ketosis [48]. They reduce portion size and, consequently, energy intake. Because it is considered to be so difficult to follow, a VLED is usually implemented short-term, aiming for rapid weight loss, and is comprised of meal replacement products (e.g., shakes, bars, soups, or desserts) to achieve a nutritionally adequate diet.

Studies in adolescents with obesity have demonstrated that a VLED can safely induce rapid weight loss in the short-term (6 to $15 \mathrm{~kg}$ over 3 to 12 weeks), while preserving lean body mass [38,39,49]. Studies have also demonstrated improvements in blood pressure, total cholesterol, HDL-C, LDL-C, triglycerides, fasting insulin, fasting glucose, glycosylated haemoglobin (HbA1c), and insulin sensitivity [38,39,49]. One of these studies found that a short-term (10 weeks) daily VLED (600-800 kcal/day) compared with a hypocaloric low-fat diet produced significantly greater reductions in percentage overweight and body fat (\%) while maintaining fat free mass [38]. In another study comparing a VLED with a hypocaloric low-fat diet, weight loss was greater in the VLED group at 4 months but this was not sustained at 12 months [39]. That study did not demonstrate any differences in cardio-metabolic outcomes, including insulin, insulin resistance, and glucose levels at any time point [39]. In one other study, a daily VLED for a mean of 60 days was effective in decreasing the BMI and improving HbA1c in adolescents with obesity and T2DM [49].

Findings indicate that VLEDs are tolerated by adolescents and result in rapid weight loss, improvements in body composition, and improved metabolic risk profile, but sustainability of long-term results is not clear. The diet, although strict, may be an alternative to pharmacological therapies or surgical interventions to treat adolescents with severe obesity. However, VLEDs require intensive monitoring by a team of health professionals and it is unclear whether they convey a particular benefit on cardio-metabolic outcomes beyond advantages from weight loss.

\section{Intermittent Modified Fasting}

Daily modest caloric restriction can be difficult to sustain and it may be very difficult to adhere to a VLED. Therefore, a viable alternative may be intermittent modified fasting, popularised as the 5:2 diet, which has gained recent media interest and celebrity endorsement. This diet regimen typically includes one to four "fasting" (or VLED) days per week, where energy intake is drastically limited (typically less than $600 \mathrm{kcal}$ ), and three to six "feeding" days per week, where food is either consumed ad libitum or a diet based on healthy eating guidelines is prescribed. It is possible that intermittent modified fasting comprised of shorter periods of energy restriction coupled with longer periods of habitual energy intake may be more sustainable and promote better adherence than continuous daily energy restriction [50].

In adults, there is evidence that intermittent fasting is effective in the short-term (eight weeks to six months) to help individuals with obesity lose body weight $(4 \%-8 \%)$ and body fat, and improve insulin sensitivity and other risk factors for T2DM [50-60]. Certain studies demonstrate 
that intermittent fasting may be more effective for inducing such improvements rather than daily energy restriction due to an overall reduction in energy intake [55,59,60]. One study, conducted in young (pre-menopausal) adult women, found that weight loss was similar but fasting insulin and insulin resistance were both reduced to a greater extent in the intermittent fasting compared with the daily caloric restriction group [60]. Benefits of an intermittent modified fast diet strategy have been postulated to extend to reducing cancer risk and increasing the healthy lifespan of adults [61]. To date, studies examining the effectiveness of intermittent modified fasting have not been conducted in youth and findings from adult studies may not be directly applicable to a child or adolescent population.

\section{Discussion}

This review highlights the importance of weight loss in children and adolescents with obesity at increased risk of T2DM, supporting an adult review which suggests that a $10 \%$ weight loss conveys an $80 \%$ reduction in the incidence of T2DM [62]. Beyond weight loss, various dietary patterns that alter the quantity and quality of carbohydrates are discussed.

Reducing the quantity of carbohydrates in the diet may be an important strategy for reducing the risk of T2DM in youth via demonstrated effects on fasting insulin, insulin resistance, and glycaemic status, irrespective of weight change (Table 3). This may be achieved by prescribing a diet that is explicitly reduced in carbohydrates, such as a very low-carbohydrate diet or a VLED, or by altering the types of foods consumed or the pattern of consumption, such as a lower-GI diet or an intermittent fasting diet, which ultimately reduce the glycaemic load of the diet.

Table 3. Pros and cons of reducing carbohydrate in the diet.

\begin{tabular}{|c|c|}
\hline Pros & Cons \\
\hline \multicolumn{2}{|l|}{$\begin{array}{l}\text { Improved fasting insulin, insulin resistance and } \\
\text { glycaemic status, irrespective of weight change }\end{array}$} \\
\hline $\begin{array}{l}\text { Can be achieved via explicit carbohydrate reduction } \\
\text { or altering dietary pattern }\end{array}$ & $\begin{array}{l}\text { Increased fatigue could result in reduced desire to } \\
\text { complete physical activity }\end{array}$ \\
\hline Facilitates reduction in hepatic fat & $\begin{array}{l}\text { May be difficult to follow long-term due to the } \\
\text { required carbohydrate restriction }\end{array}$ \\
\hline Facilitates reduction in inflammation & $\begin{array}{l}\text { Reduced intake of fibre and phytochemicals if } \\
\text { vegetable intake not suitably increased }\end{array}$ \\
\hline $\begin{array}{l}\text { Several diet strategies available to achieve reduced } \\
\text { carbohydrate allowing individualisation of the diet to } \\
\text { the patient }\end{array}$ & More research needed to support their use in youth \\
\hline Greater short-term weight loss & \\
\hline
\end{tabular}

A recent review of adult studies similarly reports the important role of reducing dietary carbohydrates for the treatment of T2DM [63]. In fact, that review strongly suggests reappraisal of dietary recommendations, and that a low-fat high-carbohydrate diet be implemented for T2DM prevention and treatment, presenting 12 points of strong evidence from various research studies for why a reduced carbohydrate diet would be advantageous. However, current guidelines supporting the prescription of a low-fat, high-carbohydrate diet are based on findings from the largest T2DM prevention studies in adults which demonstrate such a diet to be highly effective in the prevention of T2DM when compared with no treatment [19-23]. Studies of the same magnitude are yet to be conducted using a reduced carbohydrate diet intervention making it difficult for guideline committees to introduce reduced carbohydrate diets into recommendations.

It appears intuitive to place an individual with insulin resistance or pre-diabetes on a lower carbohydrate diet. Presumably, a high-carbohydrate diet in these individuals would put additional pressure on an already stressed system that would result in higher glucose and insulin levels throughout the day [26]. Ultimately, this may predispose individuals to further blood lipid abnormalities and hypertension, which increases the risk for future cardiovascular disease as well as T2DM. 
There is evidence from adult studies to suggest that the greater the carbohydrate restriction, the greater the improvement in T2DM risk factors [64]. As previously described, increased-protein diets with a carbohydrate content of 35\%-50\% did not improve insulin resistance and/or glycaemic status in children and adolescents compared with a standard-protein diet with carbohydrate content ranging from $50 \%$ to $60 \%$. This suggests that carbohydrate content may need to be below $35 \%$ of energy intake to convey a benefit.

One hypothesised mechanism for the effect of a reduced carbohydrate diet in the prevention of T2DM is the effect on hepatic lipid content. Studies in adolescents have demonstrated that independent of total and visceral fat, hepatic fat is associated with glucose dysregulation, insulin resistance, and the metabolic syndrome $[65,66]$. Accumulation of fat in the liver leads to an increase in fat delivery to all body tissues, including the pancreas, which affects the islet cells of the pancreas and eventually down-regulates beta cell function [67]. Reducing the glycaemic load of the diet may facilitate reductions in hepatic fat by reducing postprandial glucose and insulin levels, leading to less hepatic glucose absorption and reduced hepatic lipid accumulation $[24,25,68]$.

Another mechanism may be a reduction in inflammation achieved by reducing carbohydrate intake. Specifically, in the DiOGenes study, a main finding in adult participants was a significant decrease in inflammatory marker high-sensitivity C-reactive protein in lower-GI diet groups only, independent of protein content and weight change [69]. This finding was proposed to be related to reductions in postprandial glucose levels achieved through the lower-GI diet, with glucose known to stimulate the expression of inflammatory genes by epigenetic mechanisms [70-72].

The process of ketosis, such as in a very low-carbohydrate diet or a VLED, may also affect changes in insulin resistance and/or glycaemic status. The cardio-metabolic benefits of a ketogenic diet have been hypothesised to be due to weight loss. However, in both adult and paediatric studies, the effect on cardio-metabolic outcomes has been demonstrated to be more pronounced in a ketogenic diet compared with other diets, even with similar weight loss [27-29,73]. Mechanisms are not well understood but ketogenic diets have been demonstrated to specifically alter gene expression which may directly affect insulin signalling, insulin sensitivity, and glucose regulation, independent of weight change [74-76]. Urine ketone bodies have been identified in participants in studies not aiming for ketosis nor prescribing dietary carbohydrate levels consistent with ketone body production, including in an intermittent fasting intervention $[58,60,77]$. This suggests that ketosis benefits may be attained even with the prescription of more moderate carbohydrate intake.

There are negative aspects associated with a reduced carbohydrate diet that should be considered when deciding what type of diet should be prescribed to a patient (Table 3). Following a very low-carbohydrate diet has been demonstrated to lead to increased feelings of fatigue in adult men [78]. We speculate that this could result in a reduced desire to complete physical activity; especially in youth who are overweight or obese. This should especially be considered in an individual who is, or plans to be, very active as part of their weight loss regimen. It is of additional concern due to the well-established benefit of ongoing physical activity on maintenance of weight loss.

A very low-carbohydrate diet may be difficult for some individuals to follow long-term due to the required restriction of carbohydrate foods. While restricting or disallowing certain foods early on may assist in adherence due to limited food choices, this same aspect is likely to lead to boredom and may result in an inability to continue following the diet causing possible weight regain. This aspect is supported by the finding from our systematic review in youth that, short-term, a very low-carbohydrate diet led to greater weight loss compared with a high-carbohydrate diet, but longer-term weight loss was not significantly different, possibly due to eventual migration to a more typical carbohydrate intake [12].

Another issue is that restricting carbohydrates in the diet, without a sufficient increase in vegetable consumption, reduces the intake of nutrients obtained from high quality carbohydrates, particularly fibre and phytochemicals. A reduction in fibre intake in particular may increase the risk for gastrointestinal tract disorders. However, foods that contain such nutrients, such as whole grains, 
legumes, fruits, and vegetables, are typically lacking in a Western diet. Similarly, consuming lower-GI foods does not necessarily translate to consumption of healthier foods, with some ice cream, cakes, and potato crisps considered to be lower-GI. Furthermore, the GI of a food can vary between individuals and may not be directly applicable to children and adolescents at increased risk of T2DM [79].

An additional challenge is the difficulty defining which children and adolescents are at greatest risk of developing T2DM. For the purpose of this review we have widely defined youth with obesity as being at increased risk. However, those with insulin resistance and/or pre-diabetes may be assumed to be at greater risk. This is based on research that proposes that the transition from insulin resistance to pre-diabetes and type 2 diabetes occurs quite rapidly in youth [80]. However, more research is needed in this area to determine the speed and nature of this progression. Furthermore, the inconsistencies in reported findings could, in part, be due to the differences in the genetic background of individuals or populations in the included studies. However, this was not explored in the present review.

More high quality intervention studies are needed in youth to determine the association between carbohydrate intake and reduced risk of developing T2DM. However, if an association becomes clear, there appears to be several diet strategies that could be utilised to achieve a diet reduced in carbohydrates, including a very low-carbohydrate diet, a VLED, a lower-GI diet, and an intermittent fasting diet. This array of dietary options enables clinicians to offer a number of diet strategies to youth at increased risk of developing T2DM. Hence, diets may be personalised depending on patient preference and suitability.

\section{Conclusions}

Dietary research conducted in youth that measure T2DM risk factors and that compare macronutrient distributions and/or dietary patterns is limited. However, from the current body of evidence it appears that a diet that is lower in carbohydrates, irrespective of dietary strategy, may be particularly beneficial for improving risk factors for T2DM in youth.

Acknowledgments: Megan L. Gow's Doctorate of Philosophy candidature was supported by a University of Sydney Australian Postgraduate Award.

Author Contributions: Megan L. Gow drafted and finalized the content of the manuscript for submission. Sarah P. Garnett, Louise A. Baur and Natalie B. Lister reviewed the manuscript and approved the final submitted manuscript.

Conflicts of Interest: The authors declare no conflict of interest.

\section{References}

1. Fazeli Farsani, S.; van der Aa, M.P.; van der Vorst, M.M.; Knibbe, C.A.; de Boer, A. Global trends in the incidence and prevalence of type 2 diabetes in children and adolescents: A systematic review and evaluation of methodological approaches. Diabetologia 2013, 56, 1471-1488. [CrossRef] [PubMed]

2. Kitagawa, T.; Owada, M.; Urakami, T.; Yamauchi, K. Increased incidence of non-insulin dependent diabetes mellitus among Japanese schoolchildren correlates with an increased intake of animal protein and fat. Clin. Pediatr. 1998, 37, 111-115.

3. Constantino, M.I.; Molyneaux, L.; Limacher-Gisler, F.; Al-Saeed, A.; Luo, C.; Wu, T.; Twigg, S.M.; Yue, D.K.; Wong, J. Long-term complications and mortality in young-onset diabetes: Type 2 diabetes is more hazardous and lethal than type 1 diabetes. Diabetes Care 2013, 36, 3863-3869. [CrossRef] [PubMed]

4. Today Study Group. Rapid rise in hypertension and nephropathy in youth with type 2 diabetes: The TODAY clinical trial. Diabetes Care 2013, 36, 1735-1741.

5. Today Study Group. Retinopathy in youth with type 2 diabetes participating in the TODAY clinical trial. Diabetes Care 2013, 36, 1772-1774.

6. Search for Diabetes in Youth Study Group. Peripheral neuropathy in adolescents and young adults with type 1 and type 2 diabetes from the SEARCH for Diabetes in Youth follow-up cohort: A pilot study. Diabetes Care 2013, 36, 3903-3908. 
7. Mayer-Davis, E.J.; Davis, C.; Saadine, J.; D’Agostino, R.B.; Dabelea, D.; Dolan, L.; Garg, S.; Lawrence, J.M.; Pihoker, C.; Rodriguez, B.L.; et al. Diabetic retinopathy in the SEARCH for Diabetes in Youth Cohort: A pilot study. Diabet. Med. 2012, 29, 1148-1152. [CrossRef] [PubMed]

8. Zimmet, P.; Alberti, K.G.; Kaufman, F.; Tajima, N.; Silink, M.; Arslanian, S.; Wong, G.; Bennett, P.; Shaw, J.; Caprio, S.; et al. The metabolic syndrome in children and adolescents-An IDF consensus report. Pediatr. Diabetes 2007, 8, 299-306. [CrossRef] [PubMed]

9. Ho, M.; Garnett, S.P.; Baur, L.; Burrows, T.; Stewart, L.; Neve, M.; Collins, C.E. Effectiveness of lifestyle interventions in child obesity: Systematic review with meta-analysis. Pediatrics 2012, 130, e1647-e1671. [CrossRef] [PubMed]

10. Oude Luttikhuis, H.; Baur, L.; Jansen, H.; Shrewsbury, V.A.; O’Malley, C.; Stolk, R.P.; Summerbell, C.D. Interventions for treating obesity in children. Cochrane Datebase Syst. Rev. 2009. [CrossRef]

11. Collins, C.E.; Warren, J.; Neve, M.; McCoy, P.; Stokes, B.J. Measuring effectiveness of dietetic interventions in child obesity: A systematic review of randomized trials. Arch. Pediatr. Adolesc. Med. 2006, 160, 906-922. [CrossRef] [PubMed]

12. Gow, M.L.; Ho, M.; Burrows, T.L.; Baur, L.A.; Stewart, L.; Hutchesson, M.J.; Cowell, C.T.; Collins, C.E.; Garnett, S.P. Impact of dietary macronutrient distribution on BMI and cardiometabolic outcomes in overweight and obese children and adolescents: A systematic review. Nutr. Rev. 2014, 72, 453-470. [CrossRef]

13. Epstein, L.H.; Wing, R.R.; Koeske, R.; Valoski, A. Effects of diet plus exercise on weight change in parents and children. J. Consult. Clin. Psychol. 1984, 52, 429-437. [CrossRef] [PubMed]

14. Saelens, B.E.; Sallis, J.F.; Wilfley, D.E.; Patrick, K.; Cella, J.A.; Buchta, R. Behavioral weight control for overweight adolescents initiated in primary care. Obes. Res. 2002, 10, 22-32. [CrossRef] [PubMed]

15. Reinehr, T.; Schaefer, A.; Winkel, K.; Finne, E.; Toschke, A.M.; Kolip, P. An effective lifestyle intervention in overweight children: Findings from a randomized controlled trial on "Obeldicks light". Clin. Nutr. 2010, 29, 331-336. [CrossRef] [PubMed]

16. Nemet, D.; Barzilay-Teeni, N.; Eliakim, A. Treatment of childhood obesity in obese families. J. Pediatr. Endocrinol. Metab. 2008, 21, 461-467. [CrossRef] [PubMed]

17. Ben Ounis, O.; Elloumi, M.; Zouhal, H.; Makni, E.; Denguezli, M.; Amri, M.; Lac, G.; Tabka, Z. Effect of individualized exercise training combined with diet restriction on inflammatory markers and IGF-1/IGFBP-3 in obese children. Ann. Nutr. Metab. 2010, 56, 260-266. [CrossRef] [PubMed]

18. Balagopal, P.; Bayne, E.; Sager, B.; Russell, L.; Patton, N.; George, D. Effect of lifestyle changes on whole-body protein turnover in obese adolescents. Int. J. Obes. Relat. Metab. Disord. 2003, 27, 1250-1257. [CrossRef] [PubMed]

19. Knowler, W.C.; Barrett-Connor, E.; Fowler, S.E.; Hamman, R.F.; Lachin, J.M.; Walker, E.A.; Nathan, D.M.; Diabetes Prevention Program Research Group. Reduction in the incidence of type 2 diabetes with lifestyle intervention or metformin. N. Engl. J. Med. 2002, 346, 393-403. [PubMed]

20. Tuomilehto, J.; Lindstrom, J.; Eriksson, J.G.; Valle, T.T.; Hamalainen, H.; Ilanne-Parikka, P.; Keinanen-Kiukaanniemi, S.; Laakso, M.; Louheranta, A.; Rastas, M.; et al. Prevention of type 2 diabetes mellitus by changes in lifestyle among subjects with impaired glucose tolerance. N. Engl. J. Med. 2001, 344, 1343-1350. [CrossRef] [PubMed]

21. Lindstrom, J.; Ilanne-Parikka, P.; Peltonen, M.; Aunola, S.; Eriksson, J.G.; Hemio, K.; Hamalainen, H.; Harkonen, P.; Keinanen-Kiukaanniemi, S.; Laakso, M.; et al. Sustained reduction in the incidence of type 2 diabetes by lifestyle intervention: Follow-up of the Finnish Diabetes Prevention Study. Lancet 2006, 368, 1673-1679. [CrossRef]

22. Lindstrom, J.; Louheranta, A.; Mannelin, M.; Rastas, M.; Salminen, V.; Eriksson, J.; Uusitupa, M.; Tuomilehto, J.; Finnish Diabetes Prevention Study Group. The Finnish Diabetes Prevention Study (DPS): Lifestyle intervention and 3-year results on diet and physical activity. Diabetes Care 2003, 26, 3230-3236. [CrossRef] [PubMed]

23. Hamman, R.F.; Wing, R.R.; Edelstein, S.L.; Lachin, J.M.; Bray, G.A.; Delahanty, L.; Hoskin, M.; Kriska, A.M.; Mayer-Davis, E.J.; Pi-Sunyer, X.; et al. Effect of weight loss with lifestyle intervention on risk of diabetes. Diabetes Care 2006, 29, 2102-2107. [CrossRef] [PubMed]

24. Buyken, A.E.; Mitchell, P.; Ceriello, A.; Brand-Miller, J. Optimal dietary approaches for prevention of type 2 diabetes: A life-course perspective. Diabetologia 2010, 53, 406-418. [CrossRef] [PubMed] 
25. Abete, I.; Astrup, A.; Martinez, J.A.; Thorsdottir, I.; Zulet, M.A. Obesity and the metabolic syndrome: Role of different dietary macronutrient distribution patterns and specific nutritional components on weight loss and maintenance. Nutr. Rev. 2010, 68, 214-231. [CrossRef] [PubMed]

26. Liebman, M. When and why carbohydrate restriction can be a viable option. Nutrition 2014, 30, 748-754. [CrossRef] [PubMed]

27. Krebs, N.F.; Gao, D.; Gralla, J.; Collins, J.S.; Johnson, S.L. Efficacy and safety of a high protein, low carbohydrate diet for weight loss in severely obese adolescents. J. Pediatr. 2010, 157, 252-258. [CrossRef] [PubMed]

28. Kirk, S.; Brehm, B.; Saelens, B.E.; Woo, J.G.; Kissel, E.; D’Alessio, D.; Bolling, C.; Daniels, S.R. Role of carbohydrate modification in weight management among obese children: A randomized clinical trial. J. Pediatr. 2012, 161, 320-327. [CrossRef] [PubMed]

29. Demol, S.; Yackobovitch-Gavan, M.; Shalitin, S.; Nagelberg, N.; Gillon-Keren, M.; Phillip, M. Low-carbohydrate (low \& high-fat) versus high-carbohydrate low-fat diets in the treatment of obesity in adolescents. Acta Paediatr. 2009, 98, 346-351. [PubMed]

30. Westerterp-Plantenga, M.S.; Lemmens, S.G.; Westerterp, K.R. Dietary protein-Its role in satiety, energetics, weight loss and health. Br. J. Nutr. 2012, 108, S105-S112. [CrossRef] [PubMed]

31. Garnett, S.P.; Gow, M.L.; Ho, M.; Baur, L.A.; Noakes, M.; Woodhead, H.J.; Broderick, C.R.; Chisholm, K.; Briody, J.; De, S.; et al. Improved insulin sensitivity and body composition, irrespective of macronutrient intake, after a 12 month intervention in adolescents with pre-diabetes; RESIST a randomised control trial. BMC Pediatr. 2014, 14, 289. [CrossRef] [PubMed]

32. Truby, H.; Baxter, K.; Ware, R.S.; Jensen, D.E.; Cardinal, J.W.; Warren, J.M.; Daniels, L.; Davies, P.S.; Barrett, P.; Blumfield, M.L.; et al. A randomized controlled trial of two different macronutrient profiles on weight, body composition and metabolic parameters in obese adolescents seeking weight loss. PLoS ONE 2016, 11, e0151787. [CrossRef] [PubMed]

33. Wycherley, T.P.; Moran, L.J.; Clifton, P.M.; Noakes, M.; Brinkworth, G.D. Effects of energy-restricted high-protein, low-fat compared with standard-protein, low-fat diets: A meta-analysis of randomized controlled trials. Am. J. Clin. Nutr. 2012, 96, 1281-1298. [CrossRef] [PubMed]

34. Parillo, M.; Licenziati, M.R.; Vacca, M.; de Marco, D.; Iannuzzi, A. Metabolic changes after a hypocaloric, low-glycemic-index diet in obese children. J. Endocrinol. Investig. 2012, 35, 629-633.

35. Iannuzzi, A.; Licenziati, M.R.; Vacca, M.; de Marco, D.; Cinquegrana, G.; Laccetti, M.; Bresciani, A.; Covetti, G.; Iannuzzo, G.; Rubba, P.; et al. Comparison of two diets of varying glycemic index on carotid subclinical atherosclerosis in obese children. Heart Vessels 2009, 24, 419-424. [CrossRef] [PubMed]

36. Joslowski, G.; Halim, J.; Goletzke, J.; Gow, M.; Ho, M.; Louie, J.C.; Buyken, A.E.; Cowell, C.T.; Garnett, S.P. Dietary glycemic load, insulin load, and weight loss in obese, insulin resistant adolescents: RESIST study. Clin. Nutr. 2015, 34, 89-94. [CrossRef] [PubMed]

37. Damsgaard, C.T.; Papadaki, A.; Jensen, S.M.; Ritz, C.; Dalskov, S.M.; Hlavaty, P.; Saris, W.H.; Martinez, J.A.; Handjieva-Darlenska, T.; Andersen, M.R.; et al. Higher protein diets consumed ad libitum improve cardiovascular risk markers in children of overweight parents from eight European countries. J. Nutr. 2013, 143, 810-817. [CrossRef] [PubMed]

38. Figueroa-Colon, R.; von Almen, T.K.; Franklin, F.A.; Schuftan, C.; Suskind, R.M. Comparison of two hypocaloric diets in obese children. Am. J. Dis. Child. 1993, 147, 160-166. [CrossRef] [PubMed]

39. Berkowitz, R.I.; Wadden, T.A.; Gehrman, C.A.; Bishop-Gilyard, C.T.; Moore, R.H.; Womble, L.G.; Cronquist, J.L.; Trumpikas, N.L.; Levitt Katz, L.E.; Xanthopoulos, M.S. Meal replacements in the treatment of adolescent obesity: A randomized controlled trial. Obesity 2011, 19, 1193-1199. [PubMed]

40. Brand-Miller, J.; McMillan-Price, J.; Steinbeck, K.; Caterson, I. Dietary glycemic index: Health implications. J. Am. Coll. Nutr. 2009, 28, 446S-449S. [CrossRef] [PubMed]

41. Davis, J.N.; Ventura, E.E.; Shaibi, G.Q.; Weigensberg, M.J.; Spruijt-Metz, D.; Watanabe, R.M.; Goran, M.I. Reduction in added sugar intake and improvement in insulin secretion in overweight Latina Adolescents. Metab. Syndr. Relat. Disord. 2007, 5, 183-193. [CrossRef] [PubMed]

42. Brand-Miller, J.; Hayne, S.; Petocz, P.; Colagiuri, S. Low-glycemic index diets in the management of diabetes: A meta-analysis of randomized controlled trials. Diabetes Care 2003, 26, 2261-2267. [CrossRef] [PubMed]

43. Kong, A.P.; Chan, R.S.; Nelson, E.A.; Chan, J.C. Role of low-glycemic index diet in management of childhood obesity. Obes. Rev. 2011, 12, 492-498. [CrossRef] [PubMed] 
44. Gellar, L.; Nansel, T.R. High and low glycemic index mixed meals and blood glucose in youth with type 2 diabetes or impaired glucose tolerance. J. Pediatr. 2009, 154, 455-458. [CrossRef] [PubMed]

45. Abete, I.; Parra, D.; Martinez, J.A. Energy-restricted diets based on a distinct food selection affecting the glycemic index induce different weight loss and oxidative response. Clin. Nutr. 2008, 27, 545-551. [CrossRef] [PubMed]

46. Larsen, T.M.; Dalskov, S.M.; van Baak, M.; Jebb, S.A.; Papadaki, A.; Pfeiffer, A.F.; Martinez, J.A.; Handjieva-Darlenska, T.; Kunesova, M.; Pihlsgard, M.; et al. Diets with high or low protein content and glycemic index for weight-loss maintenance. NEJM 2010, 363, 2102-2113. [CrossRef] [PubMed]

47. Papadaki, A.; Linardakis, M.; Larsen, T.M.; van Baak, M.A.; Lindroos, A.K.; Pfeiffer, A.F.H.; Martinez, J.A.; Handjieva-Darlenska, T.; Kunesova, M.; Holst, C.; et al. The effect of protein and glycemic index on children's body composition: The DiOGenes randomized study. Pediatrics 2010, 126, E1143-E1152. [CrossRef] [PubMed]

48. National Health and Medical Research Council. Clinical Practice Guidelines for the Managment of Overweight and Obesity in Adults, Adolescents and Children in Australia, 2013. Available online: http://www.nhmrc.gov.au/guidelines/publications/n57 (accessed on 21 August 2015).

49. Willi, S.M.; Martin, K.; Datko, F.M.; Brant, B.P. Treatment of type 2 diabetes in childhood using a very-low-calorie diet. Diabetes Care 2004, 27, 348-353. [CrossRef] [PubMed]

50. Varady, K.A.; Bhutani, S.; Church, E.C.; Klempel, M.C. Short-term modified alternate-day fasting: A novel dietary strategy for weight loss and cardioprotection in obese adults. Am. J. Clin. Nutr. 2009, 90, 1138-1143. [CrossRef] [PubMed]

51. Bhutani, S.; Klempel, M.C.; Berger, R.A.; Varady, K.A. Improvements in coronary heart disease risk indicators by alternate-day fasting involve adipose tissue modulations. Obesity 2010, 18, 2152-2159. [CrossRef] [PubMed]

52. Bhutani, S.; Klempel, M.C.; Kroeger, C.M.; Trepanowski, J.F.; Varady, K.A. Alternate day fasting and endurance exercise combine to reduce body weight and favorably alter plasma lipids in obese humans. Obesity 2013, 21, 1370-1379. [CrossRef] [PubMed]

53. Klempel, M.C.; Kroeger, C.M.; Varady, K.A. Alternate day fasting (ADF) with a high-fat diet produces similar weight loss and cardio-protection as ADF with a low-fat diet. Metabolism 2013, 62, 137-143. [CrossRef] [PubMed]

54. Kroeger, C.M.; Klempel, M.C.; Bhutani, S.; Trepanowski, J.F.; Tangney, C.C.; Varady, K.A. Improvement in coronary heart disease risk factors during an intermittent fasting/calorie restriction regimen: Relationship to adipokine modulations. Nutr. Metab. 2012, 9, 98. [CrossRef] [PubMed]

55. Varady, K.A.; Bhutani, S.; Klempel, M.C.; Lamarche, B. Improvements in LDL particle size and distribution by short-term alternate day modified fasting in obese adults. Br. J. Nutr. 2011, 105, 580-583. [CrossRef] [PubMed]

56. Varady, K.A.; Hudak, C.S.; Hellerstein, M.K. Modified alternate-day fasting and cardioprotection: Relation to adipose tissue dynamics and dietary fat intake. Metabolism 2009, 58, 803-811. [CrossRef] [PubMed]

57. Ash, S.; Reeves, M.M.; Yeo, S.; Morrison, G.; Carey, D.; Capra, S. Effect of intensive dietetic interventions on weight and glycaemic control in overweight men with Type II diabetes: A randomised trial. Int. J. Obes. Relat. Metab. Disord. 2003, 27, 797-802. [CrossRef] [PubMed]

58. Johnson, J.B.; Summer, W.; Cutler, R.G.; Martin, B.; Hyun, D.H.; Dixit, V.D.; Pearson, M.; Nassar, M.; Telljohann, R.; Maudsley, S.; et al. Alternate day calorie restriction improves clinical findings and reduces markers of oxidative stress and inflammation in overweight adults with moderate asthma. Free Radic. Biol. Med. 2007, 42, 665-674. [CrossRef] [PubMed]

59. Harvie, M.; Wright, C.; Pegington, M.; McMullan, D.; Mitchell, E.; Martin, B.; Cutler, R.G.; Evans, G.; Whiteside, S.; Maudsley, S.; et al. The effect of intermittent energy and carbohydrate restriction v. daily energy restriction on weight loss and metabolic disease risk markers in overweight women. Br. J. Nutr. 2013, 110, 1534-1547. [CrossRef] [PubMed]

60. Harvie, M.N.; Pegington, M.; Mattson, M.P.; Frystyk, J.; Dillon, B.; Evans, G.; Cuzick, J.; Jebb, S.A.; Martin, B.; Cutler, R.G.; et al. The effects of intermittent or continuous energy restriction on weight loss and metabolic disease risk markers: A randomized trial in young overweight women. Int. J. Obes. 2011, 35, 714-727. [CrossRef] [PubMed] 
61. Brandhorst, S.; Choi, I.Y.; Wei, M.; Cheng, C.W.; Sedrakyan, S.; Navarrete, G.; Dubeau, L.; Yap, L.P.; Park, R.; Vinciguerra, M.; et al. A periodic diet that mimics fasting promotes multi-system regeneration, enhanced cognitive performance, and healthspan. Cell Metab. 2015, 22, 86-99. [CrossRef] [PubMed]

62. Grams, J.; Garvey, W.T. Weight loss and the prevention and treatment of type 2 diabetes using lifestyle therapy, pharmacotherapy, and bariatric surgery: Mechanisms of action. Curr. Obes. Rep. 2015, 4, 287-302. [CrossRef] [PubMed]

63. Feinman, R.D.; Pogozelski, W.K.; Astrup, A.; Bernstein, R.K.; Fine, E.J.; Westman, E.C.; Accurso, A.; Frassetto, L.; Gower, B.A.; McFarlane, S.I.; et al. Dietary carbohydrate restriction as the first approach in diabetes management: Critical review and evidence base. Nutrition 2015, 31, 1-13. [CrossRef] [PubMed]

64. Volek, J.S.; Feinman, R.D. Carbohydrate restriction improves the features of Metabolic Syndrome. Metabolic Syndrome may be defined by the response to carbohydrate restriction. Nutr. Metab. 2005, 2, 31. [CrossRef] [PubMed]

65. Cali, A.M.; de Oliveira, A.M.; Kim, H.; Chen, S.; Reyes-Mugica, M.; Escalera, S.; Dziura, J.; Taksali, S.E.; Kursawe, R.; Shaw, M.; et al. Glucose dysregulation and hepatic steatosis in obese adolescents: Is there a link? Hepatology 2009, 49, 1896-1903. [CrossRef] [PubMed]

66. D'Adamo, E.; Cali, A.M.; Weiss, R.; Santoro, N.; Pierpont, B.; Northrup, V.; Caprio, S. Central role of fatty liver in the pathogenesis of insulin resistance in obese adolescents. Diabetes Care 2010, 33, 1817-1822. [CrossRef] [PubMed]

67. Al-Khalifa, A.; Mathew, T.C.; Al-Zaid, N.S.; Mathew, E.; Dashti, H.M. Therapeutic role of low-carbohydrate ketogenic diet in diabetes. Nutrition 2009, 25, 1177-1185. [CrossRef] [PubMed]

68. Lang, V.; Bornet, F.R.; Vaugelade, P.; van Ypersele de Strihou, M.; Luo, J.; Pacher, N.; Rossi, F.; la Droitte, P.; Duee, P.H.; Slama, G. Euglycemic hyperinsulinemic clamp to assess posthepatic glucose appearance after carbohydrate loading. Am. J. Clin. Nutr. 1999, 69, 1183-1188. [PubMed]

69. Gogebakan, O.; Kohl, A.; Osterhoff, M.A.; van Baak, M.A.; Jebb, S.A.; Papadaki, A.; Martinez, J.A.; Handjieva-Darlenska, T.; Hlavaty, P.; Weickert, M.O.; et al. Effects of weight loss and long-term weight maintenance with diets varying in protein and glycemic index on cardiovascular risk factors: The diet, obesity, and genes (DiOGenes) study: A randomized, controlled trial. Circulation 2011, 124, 2829-2838. [CrossRef] [PubMed]

70. Kolb, H.; Mandrup-Poulsen, T. The global diabetes epidemic as a consequence of lifestyle-induced low-grade inflammation. Diabetologia 2010, 53, 10-20. [CrossRef] [PubMed]

71. Brasacchio, D.; Okabe, J.; Tikellis, C.; Balcerczyk, A.; George, P.; Baker, E.K.; Calkin, A.C.; Brownlee, M.; Cooper, M.E.; El-Osta, A. Hyperglycemia induces a dynamic cooperativity of histone methylase and demethylase enzymes associated with gene-activating epigenetic marks that coexist on the lysine tail. Diabetes 2009, 58, 1229-1236. [CrossRef] [PubMed]

72. El-Osta, A.; Brasacchio, D.; Yao, D.; Pocai, A.; Jones, P.L.; Roeder, R.G.; Cooper, M.E.; Brownlee, M. Transient high glucose causes persistent epigenetic changes and altered gene expression during subsequent normoglycemia. J. Exp. Med. 2008, 205, 2409-2417. [CrossRef] [PubMed]

73. Volek, J.S.; Phinney, S.D.; Forsythe, C.E.; Quann, E.E.; Wood, R.J.; Puglisi, M.J.; Kraemer, W.J.; Bibus, D.M.; Fernandez, M.L.; Feinman, R.D. Carbohydrate restriction has a more favorable impact on the metabolic syndrome than a low fat diet. Lipids 2009, 44, 297-309. [CrossRef] [PubMed]

74. Okuda, T.; Morita, N. A very low carbohydrate ketogenic diet increases hepatic glycosphingolipids related to regulation of insulin signalling. J. Funct. Foods 2016, 21, 70-74. [CrossRef]

75. Badman, M.K.; Kennedy, A.R.; Adams, A.C.; Pissios, P.; Maratos-Flier, E. A very low carbohydrate ketogenic diet improves glucose tolerance in ob/ob mice independently of weight loss. Am. J. Physiol. Endocrinol. Metab. 2009, 297, E1197-E1204. [CrossRef] [PubMed]

76. Clifton, P.; Carter, S.; Headland, M.; Keogh, J. Low carbohydrate and ketogenic diets in type 2 diabetes. Curr. Opin. Lipidol. 2015, 26, 594-595. [CrossRef] [PubMed]

77. Heilbronn, L.K.; Smith, S.R.; Martin, C.K.; Anton, S.D.; Ravussin, E. Alternate-day fasting in nonobese subjects: Effects on body weight, body composition, and energy metabolism. Am. J. Clin. Nutr. 2005, 81, 69-73. [PubMed]

78. White, A.M.; Johnston, C.S.; Swan, P.D.; Tjonn, S.L.; Sears, B. Blood ketones are directly related to fatigue and perceived effort during exercise in overweight adults adhering to low-carbohydrate diets for weight loss: A pilot study. J. Am. Diet. Assoc. 2007, 107, 1792-1796. [PubMed] 
79. Vega-Lopez, S.; Ausman, L.M.; Griffith, J.L.; Lichtenstein, A.H. Interindividual variability and intra-individual reproducibility of glycemic index values for commercial white bread. Diabetes Care 2007, 30, 1412-1417. [CrossRef] [PubMed]

80. Weiss, R.; Taksali, S.E.; Tamborlane, W.V.; Burgert, T.S.; Savoye, M.; Caprio, S. Predictors of changes in glucose tolerance status in obese youth. Diabetes Care 2005, 28, 902-909. [CrossRef] [PubMed]

(C) 2016 by the authors; licensee MDPI, Basel, Switzerland. This article is an open access article distributed under the terms and conditions of the Creative Commons Attribution (CC-BY) license (http://creativecommons.org/licenses/by/4.0/). 